\title{
SHIFT WORK, EMOTIONAL LABOUR AND PSYCHOLOGICAL WELL-BEING OF NURSING STAFF
}

\author{
Christel Vermaak, * Gina Görgens-Ekermans, ** Cecile Nieuwenhuize*** \\ Received: 7. 10. 2016 \\ Preliminary communication \\ Accepted: 1. 12. 2017 \\ UDC 614.253.5:159.942
}

\begin{abstract}
This study explored the effect of emotional labour and the psychological experience of shift work on the psychological well-being at work $(P W B W)$ of long term care nursing staff $(n=206)$. The 'psychological experience of shift work' construct defines the perception of the negative effect that working shifts has on the employees' daily life. Correlation and multiple regression analyses were conducted. Support was found for the negative relationships between the psychological experience of shift work and PWBW, as well as the emotional labour dimension of surface acting and $P W B W$.
\end{abstract}

\section{INTRODUCTION}

The increased life expectancy of recent years has resulted in an increased demand for long term care services which, together with the shrinking labour market of nursing staff poses a challenge for facilities providing long term care to geriatric patients. These long term care facilities include retirement villages, home-based care, mid- and frail care and organisations providing care
A hierarchical regression analysis suggested that, when controlling for the effect of emotional labour and certain demographic variables (including number of dependents, tenure and actual shift worked), a significant amount of unique variance in $P W B W$, could be accounted for by the psychological experience of shift work. These results indicate that the PWBW of nursing staff is not only influenced by which shift the individual is on (i.e. day or night shift), but more so by the individuals'psychological experience of shift work.

Keywords: shift work, emotional labour, psychological well-being, nursing

for patients affected by dementia and other age related disorders.

The growth of the aged population is resulting in an increase not only in the number of healthy years that a person can expect to enjoy, but also in the number of years living in ill health (Murray, 2015). Years lived with disabilities (YLDs) increased globally by $42 \%$ from 1990 to 2013 . The implication of the increased number of years living in

Christel Vermaak, MSc, Department of Industrial Psychology, Stellenbosch University, South Africa

** Gina Görgens-Ekermans, PhD, associate professor, Department of Industrial Psychology, Stellenbosch University, Private Bag X1, Matieland 7602, Stellenbosch, Cape Town, South Africa; Phone: +27 218083596; E-mail: ekermans@sun.ac.za

*** Cecile Nieuwenhuize, PhD, professor, Head of Department Business Management, University of Johannesburg, South Africa. 
ill health (up to 10 years; Murray, 2015) is a longer duration of long term care required. The trend of increased YLDs leads to a steep demand in nursing care for the large numbers of elderly persons. Nursing staff constitute the largest group of employees in the healthcare industry and they play a crucial role in the quality of care provided (Giallonardo et al., 2010). However, nursing staff experience the lowest levels of job engagement and the highest levels of burnout in comparison to other professional healthcare groups (Fasoli, 2010).

Therefore, it is crucial to seek a scientific understanding of the psychological processes that underlie the work-related well-being of long term care nursing staff, hereinafter referred to only as nursing staff. Increasing our understanding of the factors affecting the psychological well-being at work of nursing staff could enable organisational management to improve employees' well-being and reduce turnover. This could contribute to reducing the industry's labour shortages that ultimately influences the price of healthcare services and the performance of healthcare organisations.

\section{LITERATURE REVIEW}

\subsection{Psychological well-being of nursing staff}

In line with positive psychology (Seligman and Csikszentmihalyi, 2000), and to ensure a satisfied work force and the retention of employees, psychological well-being at work has been identified as an important consideration for business, management and care providers. According to Dagenais-Desmarais and Savoie (2012) the Psychological Well-Being at Work (PWBW) construct intends to describe an individual's subjective positive experience at work, which comprises of primarily eudaimonic dimensions. PWBW, which is well-being contextualised in the work domain, consists of five work-related dimensions. The first dimension, interpersonal fit at work, entails the perception of experiencing positive relationships with the individuals with whom one interacts at work. Second, thriving at work, refers to the perception of accomplishing a significant and interesting job that enables feelings of fulfillment. Third, feelings of competency at work, involve the perception of possessing the necessary aptitudes to efficiently perform one's job. Fourth, perceived recognition at work, refers to the perception of being appreciated within the organisation for one's work and personhood. The fifth dimension is the desire for involvement at work, which is the will to involve oneself in contributing to the organisation's functioning and success.

Khamisa et al. (2013) showed that high levels of work-related stress, burnout and poor health are common within the nursing profession. This may be due to the long working hours and frequent direct, personal and emotional contact with a large number of patients that characterises nursing work. Moreover, in a study by Pelissier et al. (2015), 36.83\% of healthcare staff report impaired mental well-being. Poor mental health affects patient safety, quality of care and nurse performance (Sexton et al., 2000), as well as the profitability of organisations; in this case, specifically long term care facilities (Cooper and Cartwright, 1994). Poor psychological well-being of employees has also been associated with increased turnover (Salanova et al., 2011; Xantopoulou et al., 2009). Exploring PWBW can provide valuable insights to businesses regarding the management of their employees in order to improve employee well-being, and ultimately individual and organisational performance. 


\subsection{The effect of emotional labour and shift work on PWBW}

Working shifts and experiencing perpetual intense emotional interactions with patients (i.e. emotional labour) are two very prominent job stressor characteristics of the daily work environment for nursing staff, which has been shown to significantly impact on their PWBW (Dall'Ora et al., 2016; Leggat et al., 2013).

The concept of emotional labour is based on the act of expressing socially desirable emotions (Ashforth and Humphrey, 1993). Employees engage in emotional labour when they attempt to regulate their emotional display to align it with the behaviour perceived as appropriate for their roles, or the expectations of the organisation. In addition to determining the content and range of emotions, these expectations also regard the frequency, intensity and duration with which these emotions should be displayed (Morris and Feldman, 1996). Emotional dissonance may be experienced upon expressing these required emotions. This occurs as a result of the incompatibility between the employees' actual feelings and those required by their work role or organisational expectations.

Merkel (2002) and Smith and Lorentzon (2005) note that in most instances emotional labour is performed by nurses to align their actual feelings with the caring emotions that they think they should experience. Empirical studies in psychology and management have identified various negative consequences of emotional labour (Hess, 2003). For example, when employees "express superficially-felt emotions" (i.e. surface acting) over an extended period of time, it results in emotional distress that may lead to emotional exhaustion and depersonalization (i.e. burnout) (Karimi et al., 2013). In addition, results by Karimi et al. (2013) indicated a significant positive relationship between surface acting and the stress associated with regular interpersonal interaction. This suggested that nurses, who display higher levels of surface acting, also reported experiencing higher levels of interaction stress. Similarly, Cheng et al. (2013) reported that surface acting (in the form of faking unfelt emotions) has a significant negative influence on the quality of care as perceived by patients. Chou et al. (2012) also found that surface acting is positively related to emotional exhaustion, whilst also being negatively related to job satisfaction.

The healthcare industry depends on nonstandard work schedules to ensure continuity of care provided. This can involve night shifts, early morning shifts, and rotating shifts including irregular schedules and shift times that varies according to the needs of the business (Liang et al., 2014). Literature on the impact of shift work on health and performance outcomes are abundant, but inconclusive. For example, in their review of numerous shift work studies Dall'Ora et al. (2016) found that shift work characteristics are associated with compromised employee's performance and well-being, but that timely breaks contributed positively to employee alertness and prevented fatigue. This suggests that if managed well, the negative implications of shift work in healthcare can be reduced. In the most recent and comprehensive review of the impact of shift work on the psychological functioning of nursing staff, Tahghighi et al. (2017) concluded that no definitive evidence was found for the association between shift work and impaired psychological functioning. The authors note that overall, the findings suggest that the aforementioned association is dependent on various individual and contextual factors (Tahghighi et al., 2017). Similarly, Von Treuer et al. (2014) found that shift work alone did not predict health outcomes, but that other contextual factors that differ 
between shifts accounts for the variation of health outcomes associated with shift work.

It is widely accepted that individuals vary in their experience of, and thus response to, the same external conditions (Pluess \& Belsky, 2013). These individual differences in the perceptions of experiences is also believed to impact physical and psychological well-being (Demartini, 2010). Subsequently, it is argued that even though employees might work similar shifts, not all employees experience the negative effect of shift work as severely as others. For example, Peters et al. (2016) found that the negative emotional effect of work schedule demands are less for nurses who experience a better fit between their work schedule and their private lives. This illustrates that the psychological experience of working shifts varies according to individual's unique circumstances. For example, employees may experience that working shifts reduces opportunities for normal social interaction and thereby developing good social support structures (Costa, 2016). Such employees may have to deal with negative emotions (e.g. guilt) due to the disruption shift works causes to their family life. Liang et al. (2014) also note the psychological effect resulting from difficulty planning for family responsibilities and maintaining routines. Therefore, even though literature on the effects of shift work on physical health (e.g. Ferri et al., 2016), as well as on family and social issues (Iskra-Golec et al., 2016) is abundant, this study argues that the psychological effect of how working shifts negatively influences the quality of life, and subsequent psychological well-being of employees, should also be investigated.

The 'psychological experience of shift work' construct measured in this study, defines the perception of the negative effect that working shifts has on the employees' daily life. The construct measures the over- all perception of the psychological effect of the experience of shift work on an employee, and the items were designed to address the most frequently reported experienced effects of shift work, including the impact on physical health, and social or family issues. It is argued that the resulting experienced psychological effects of shift work may be an important predictor of self-reported psychological well-being, above the actual experience of working shifts.

\subsection{Objective of the study}

Due to their important contribution to client service and business, the objective of this study was to explore the effect of emotional labour, and the psychological experience of shift work on the PWBW of nursing staff. Support for the established relationship between emotional labour and PWBW was expected (Leggat et al., 2013). Particularly, the impact of the surface acting sub-dimension of emotional labour was expected to emerge as a important component of emotional labour associated with PWBW (Chou et al., 2012). It was also expected that as employees reported a more negative self-reported psychological experience of working shifts, their self-reported PWBW would decrease.

Moreover, this study aimed to provide further insight into the unique variance accounted for by emotional labour and the psychological experience of working shifts in the PWBW of nursing staff, whilst controlling for demographic variables that may also influence the experience of these job stressors (e.g. number of dependents, tenure, actual shift during the survey). It was argued that these demographic factors may have effects on the experience of the relevant job stressors (e.g. emotional labour, psychological experience of shift work). For example, one could argue that as the number of dependents of a nursing assistant increases, so the stress experienced due to working shifts 
may increase - due to the logistical implications related to caring for children, or other elderly parents / family members. It could, furthermore, be argued that the actual shift the employee was working on during the administration of the survey, could significantly affect the health (physical and psychological) of the employee. Therefore, the effect of this had to be controlled for in the analysis. Moreover, it was argued that tenure could affect psychological well-being as prolonged exposure to shift work (depending on the design of the shift schedule) may have either positive or negative consequences for wellbeing. The effects of this was, therefore, also controlled for during the analysis.

In accordance with the aforementioned objectives, the ultimate purpose of this study was to derive managerial implications for the management of the PWBW of nursing staff from the results, with specific reference to experienced emotional labour and exposure to shift work.

\section{METHODOLOGY}

\subsection{Research design and data collection}

A non-experimental research design and a non-probability, convenience sampling method was utilised. The sample of 206 nursing staff, which included nursing assistants and registered nurses, were employed in four South African based long term care institutions. Hard copy questionnaires were distributed to the participants and the completed questionnaires (with informed consent forms) were placed in anonymous boxes which the researchers then collected. The response rate was $71 \%$. Ethical clearance was obtained before the study commenced.

The sample consisted of $98 \%$ females (mean age $=39, \mathrm{SD}=11)$. This severely skewed gender distribution was expected as nursing is a female dominated occupation (e.g. Tak et al., 2010). With $90.8 \%$ of the sample consisting of African individuals, the sample quite accurately reflected the race distribution of South Africa (Statistics South Africa, 2015). The sample consisted of $76.7 \%$ nursing assistants, and nurses and sisters made up the remaining $23.3 \%$. In terms of tenure, $51.9 \%$ of the sample reported being employed at the organisation for $2-5$ years, with $31.1 \%$ reporting employment of less than one year, and $12.6 \%$ reporting more than 5 years of employment (3.5\% missing data).

\subsection{Measurement instruments}

The dependant variable, PWBW, was measured with the Index of Psychological Well-being at work (IPWBW) developed by Dagenais-Desmarais and Savoie (2012). This instrument is comprised of various eudaimonic dimensions of well-being and intends to describe individuals' subjective work experience. The five dimensions include interpersonal fit at work, thriving at work, feelings of competency at work, perceived recognition at work, and desire for involvement at work. The five dimensions together represent a higher order construct of PWBW (Dagenais-Desmarais \& Savoie, 2012). The short version of the IPWBW used in this study consisted of 25 items, all measured on a 5-point Likert scale, ranging from strongly disagree (1) to strongly agree (5). Dagenais-Desmarais and Savoie (2012) demonstrated adequate internal consistency for the higher order construct (PWBW: $\alpha=.964$ ). The authors also found support for the IPWBW's convergent and divergent validity. Specifically, PWBW and its dimensions were found to be positively correlated with context-free psychological well-being $(.26 \leq r \leq .54)$, positive affect $(.35 \leq r \leq .53)$, and satisfaction with life $(.25 \leq r \leq .40)$. 
Emotional labour was measured with the Emotional Labour Scale (ELS), which is a 15-item self-report questionnaire (Brotheridge \& Lee, 2003). The ELS measures six facets of workplace emotional display including the frequency, intensity and variety of the emotional display, as well as surface acting and deep acting. The five aforementioned facets are measured using a 5-point Likert scale, whilst the duration of a typical interaction is measured in terms of minutes. No higher order emotional labour construct underlies this measure. Each facet describes a unique component of emotional labour. Brotheridge and Lee (2003) reported internal consistency estimates for the subscales ranging from .74 to .91 .

The psychological experience of shift work was measured with a 7-item scale (Psychological Experience of Shift Work scale, PESW) developed by the researchers in order to determine long term care nursing staff's perception of how working shifts such as, 'Working shifts negatively impacts my health', 'Life would be easier if I wasn't working shifts', 'Working shifts disrupts my social life' and 'I have more trouble organising my home life due to shift work'.

Due to the fact that this instrument was developed for the purposes of this study, a validation study of the factor structure was conducted. The results of the Principal Component Analysis (PCA) with Varimax rotation revealed that indeed only one factor could be extracted (one Eigen value larger than one), which explained a total of $61.13 \%$ variance. Subsequently, a confirmatory factor analysis (CFA) with LISREL 8.8 (Jöreskog and Sörbom, 2002) was conducted to further validate the instrument. The results revealed good model fit [RMSEA $=0.08$ (confidence intervals: $0.052 ; 0.078), \mathrm{NNFI}=0.98, \mathrm{CFI}=$ $0.98, \mathrm{SRMR}=0.04$; Hair et al., 2006)]. The completely standardised factor loadings ranged from .59 to .90 (all significant).

Table 1: Descriptive statistics

\begin{tabular}{ccccc}
\hline & $\begin{array}{c}\text { Number } \\
\text { of items }\end{array}$ & M & SD & $\alpha$ \\
\hline PWBW & 25 & 106.35 & 15.19 & .90 \\
PESW & 7 & 15.76 & 7.40 & .89 \\
EL_Frequency & 3 & 9.81 & 2.90 & .65 \\
EL_Intensity & 2 & 5.78 & 2.05 & .56 \\
EL_Variety & 3 & 8.72 & 2.77 & .64 \\
EL_Surface Acting & 3 & 8.41 & 2.59 & .43 \\
EL_Deep Acting & 3 & 9.25 & 2.91 & .64 \\
\hline
\end{tabular}

Note: $\mathrm{PWBW}=$ Psychological well-being at work; PESW = Psychological Experience of Shift Work; EL_freq = frequency; EL_inten = intensity; EL_var = variety; EL_surf = surface acting; EL_deep $=$ deep acting

impacts their daily lives. The scale was developed to measure one latent construct (i.e. psychological experience of shift work). Participant responses were recorded on a 5-point Likert scale ranging from 'never' to 'always' and included statements
The internal reliabilities, means and standard deviations for all three questionnaires are reported in Table 1. The item analysis results for the IPWBW indicated an acceptable reliability coefficient 
of .90 (Nunnally, 1978). The PESW scale returned a similarly high internal consistency coefficient of .89 . The reliability coefficients derived for the emotional labour facets were somewhat weaker than those reported by the authors (Brotheridge \& Lee, 2003), that ranged from .58 (intensity) to .85 (surface acting). The current item analysis returned values ranging from .43 (surface acting) to .65 (frequency). These moderate values may partly be due to the limited number of items included in each of the subscales (see

\section{RESULTS}

\subsection{Relationships between emotional labour, PESW and PWBW}

Pearson correlations between the three constructs (and their respective subdimensions) were calculated (see Table 2). Only four significant correlations emerged. This included the expected correlations between the psychological experience of shift work and psychological well-being at

Table 2: Psychological well-being at work, psychological experience of shift work, and emotional labour correlations

\begin{tabular}{cccccccc}
\hline Measure & EL_freq & EL_inten & EL_var & EL_surf & EL_deep & PWBW & PESW \\
\hline EL_freq & - & & & & & & \\
EL_inten & $.464^{* *}$ & - & & & & & \\
EL_var & $.517^{* *}$ & $.546^{* *}$ & - & & & & \\
EL_surf & $.243^{* *}$ & $.232^{* *}$ & $.439^{* *}$ & - & & & \\
EL_deep & $.584^{* *}$ & $.529^{* *}$ & $.525^{* *}$ & $.321^{* *}$ & - & & \\
PWBW & -.038 & .011 & -.102 & $-.155^{*}$ & -.039 & - & \\
PESW & .129 & .064 & $.265^{* *}$ & $.197^{* *}$ & .063 & $-.295^{* *}$ & - \\
\hline
\end{tabular}

Note: $E L \_f r e q=$ frequency; EL_inten = intensity; EL_var = variety; EL_surf = surface acting; EL_deep = deep acting; PESW $=$ Psychological Experience of shift work,${ }^{*}$ Correlation is significant at the 0.05 level (2-tailed); **Correlation is significant at the 0.01 level (2-tailed).

table 1). Nevertheless, the relatively low internal consistency results of the emotional labour subscales are noted as a limitation of this study.

\subsection{Data analysis}

The data was analysed using SPSS 22.0 and LISREL 8.8. Item analyses were performed to determine the reliability of the instruments, whilst correlation and multiple regression analyses were conducted to explore the relationships between emotional labour, the psychological experience of shift work and PWBW. work $(\mathrm{r}=-.295, \mathrm{p}<.01)$, and between the emotional labour facet of surface acting and psychological well-being at work $(r=-.155$, $\mathrm{p}<.05)$. The PESW construct also obtained significant relationships with the emotional labour facets of surface acting $(\mathrm{r}=.197, \mathrm{p}<$ $.01)$ and variety $(\mathrm{r}=.265, \mathrm{p}<.01)$. 


\subsection{Predictors of psychological well- being at work}

Hierarchical regression analysis was conducted in order to determine the effect of the independent variables, emotional labour and PESW, on the PWBW of the nursing staff, when possible variance accounted for however, that the last model (model three) was significant $(\mathrm{R} 2=0.12, \mathrm{p}=0.000)$. Moreover, the results revealed that the unique variance $(7 \%)$ accounted for by the addition of the PESW variable when controlling for emotional labour, and certain demographic characteristics, were significant (R2 change $=0.070, \mathrm{p}=0.000)$. In this model the only

Table 3: Hierarchical regression analysis results

\begin{tabular}{lccccc}
\hline \multicolumn{1}{c}{ Variable } & Model & Model & Model 3 & $\mathbf{R}^{2}$ & $\mathbf{R}^{2}$ \\
& $\mathbf{1 ~ S t d ~} \boldsymbol{\beta}$ & $\mathbf{2}$ Std $\boldsymbol{\beta}$ & Std $\boldsymbol{\beta}$ & Accumulative & Increment \\
\hline 1. Demographic variables & & & & .034 & \\
$\quad$ Number of Dependents & -.101 & -.090 & -.091 & & \\
Tenure & .108 & .098 & .088 & & \\
Actual Shift & -.140 & -.137 & $-.169^{*}$ & & .016 \\
2. EL Surface acting & & -.129 & -.077 & $.050^{*}$ & $.07^{*}$ \\
3. PESW & & & $-.271^{* *}$ & $.12^{*}$ & \\
\hline
\end{tabular}

Note. ${ }^{*} \mathrm{p}<.05 .{ }^{* *} \mathrm{p}<.01$; PESW $=$ Psychological Experience of Shift Work

by demographic variables that may influence the experience of shift work (tenure, number of dependents, actual shift the respondent was working at the time of the study) was being controlled for (Table 3). Hence, in step one of the analyses actual shift (coded as day $=1$, night $=2$ ), number of dependents, and tenure were entered as predictors. In step two, based on previous research, the most salient component of emotional labour related to well-being in nurses, i.e. surface acting (Cheng, 2013, Chou, 2012, Karimi et al., 2013), was included in the model. In step three the total score of the measure of the PESW was entered, in addition to the other predictors already in the model (model 3 ). The results revealed that the first model was insignificant $(\mathrm{p}>0.05)$. However, the second model, where surface acting was added was significant ( $p<0.05$, see Table 3 ). The amount of unique variance explained by this model was not significant (R2 change $=0.016, \mathrm{p}=0.074)$. The results revealed, two significant predictors were actual shift (i.e. day or night shift) with $\beta=-0.169$, and PESW with $\beta=-0.271$.

\section{DISCUSSION AND RECOMMENDATIONS}

Support was found for the relationship between the psychological experience of shift work and psychological well-being at work. This suggests that as employees report a more negative experience of the impact of shift work on their lives (higher scores on PESW), they also experience a more negative effect in terms of self-reported psychological well-being. This reasoning is in accordance with literature indicating that the negative impact of shift work on emotional well-being is influenced by other factors, such as nurses' private lives (which impacts their experience of shift work; Peters et al.; 2016, Tahghighi et al., 2017). Moreover, the PESW construct 
also obtained significant relationships with the emotional labour facets of surface acting and variety. This suggested that these two stressors (i.e. PESW and EL) are positively related. These results indicate that as the variety of emotions the nursing staff needs to display increases, together with the surface acting display of such emotions, the individual's coping resources probably becomes depleted and the employee would experience the psychological burden of shift work more severely - impeding their general psychological well-being.

The results further revealed that the emotional labour facet of surface acting was negatively related to psychological wellbeing at work. This is in line with previous research indicating a strong positive relationship between emotional labour and psychological well-being indicators (Karimi et al., 2013; Kinman \& Leggetter, 2016). The results of the hierarchical regression analysis suggested that, when controlling for the effect of the surface acting component of emotional labour and certain demographic variables (including number of dependents, tenure and actual shift), a significant amount of unique variance (7\%) in PWBW could be accounted for by the psychological experience of shift work. In addition to the psychological experience of shift work, actual shift (i.e. day or night shift) was the only other significant predictor of PWBW.

Taken together these results suggest that working shifts as a nursing staff member (which implies high levels of emotional and personal involvement) places a significant psychological burden on the employee, one that needs to be actively managed in order to ensure better long term sustained psychological well-being of employees. Besides considering the physical effect of shift work on employees and trying to alleviate the direct physical effects (e.g. onsite sleep- ing arrangements), the psychological effect should also be addressed through appropriate intervention programmes. Kinman and Leggetter (2016) emphasise the importance of interventions that equip nursing staff to better cope with the emotional demands of their work. Such an intervention could create awareness of the implied psychological effect and how to address this.

In essence, the results indicate that being on night shift has a significant, albeit small negative effect on PWBW. Well-managed shift work has been shown to improve employees' sense of work-life balance and their well-being (Agosti et al., 2015), which could ultimately affect the quality of care and organisational performance. However, the employees' perception of how shift work affects their lives was a much stronger predictor of their PWBW. In line with the findings of Dall'Ora et al. (2016) it is suggested that organisations could alleviate the adverse psychological effects of shift work through proper management.

\section{MANAGERIAL IMPLICATIONS}

Due to the emotionally demanding nature of nursing work and the around the clock nature of the nursing service industry, it is unlikely that the effects of emotional labour and shift work on the PWBW of nursing staff could be completely diminished. However, the adverse effects could be minimized through proper management. Health promotion programmes can assist nursing staff to cope with psychological demands (Liang et al., 2014). For example, intervention programmes that increase coping resources to buffer the effect of emotional labour on well-being (e.g. increasing Emotional Intelligence; Karimi et al., 2013) could be introduced. It is important that the 
concept of emotional labour and its psychological impact is understood, reflected on and discussed with employees, as it has an impact not only on the employees, but also on the quality of care provided. Intervention programmes designed to develop positive psychological resources could also be implemented. For example, Pisanti et al. (2015) reported that nursing staff with higher levels of occupational coping self-efficacy experienced higher levels of well-being. Evidence exist that such state-like positive psychological resources, like self-efficacy, can be developed through training initiatives (Görgens-Ekermans et al., 2015; Ouweneel et al., 2013).

It is also recommended that organisations develop tailored selection procedures that incorporate consideration of certain personal resources, such as a sense of calling. The trait-like construct of calling is particularly relevant for employees in the

\section{References}

1. Agosti, M., Anderson, I., Ejlertsson, G., \& Janlov, A. (2015). Shift work to balance everyday life - a salutogenic nursing perspective in home help service in Sweden. BMC Nursing, 14(2), 2-11.

2. Ashforth, B., \& Humphrey, R. (1993). Emotional labor in service roles: The influence of identity. Academic management review, 18(1), 88-115.

3. Brotheridge, C. M., \& Lee, R. T. (2003). Development and validation of the emotional labour scale. Journal of Occupational and Organizational Psychology, 76(3), 365-379.

4. Cheng, C., Bartram, T., Karimi, L., \& Leggat, S. (2013). The role of team climate in the management of emotional labour: implications for nurse retention. Journal of Advanced Nursing, 69 (12), 2812-2825. doi: 10.1111/jan.12202. healthcare industry as they experience higher levels of calling compared to employees in other economic sectors (Hagmaier and Abele, 2012). Calling has also been found to be significantly related to the well-being of nursing staff (Vermaak, 2016).

Strengthening colleagial support networks and enhancing a culture of support, through, for example, providing opportunities for socialization between staff members (Liang et al., 2014) could also contribute to employee well-being. Introducting stresscoping programmes with a worker-centered approach as support for shift workers is also recommended (De Cordova et al, 2016). Managerial actions to further address the effect of shift work include considering the length of shifts, the total hours worked per week, amount of overtime worked, the frequency of shift rotation and the sufficiency of rest opportunities (Dall'Ora et al., 2016).

5. Chou, H., Hecker, R., \& Martin, A. (2012). Predicting nurses' well-being from job demands and resources: a crosssectional study of emotional labour. Journal of Nursing Management, 20(4), 502-511.

6. Cooper, C., \& Cartwright, S. (1994). Healthy mind; healthy organization: A proactive approach to occupational stress. Human Relations, 47(4), 455471.

7. Costa, G. (2016). Social and Family issues in Shift Work and Non Standard Working Hours. Switzerland: Springer International Publishing.

8. Dagenais-Desmarais, V., \& Savoie, A. (2012). What is Psychological WellBeing, Really? A Grassroots Approach from the Organizational Sciences. Journal of Happiness Studies, 13, 659684. 
9. Dall'Ora, C., Ball, J., Recio-Saucedo, A., \& Griffiths, P. (2016). Characteristics of shift work and their impact on employee performance and wellbeing: A literature review. International Journal of Nursing Studies, 57, 12-27.

10. De Cordova, P.B., Bradford, M., \& Stone, P. (2016). Increased errors and decreased performance at night: A systematic review of the evidence concerning shift work and quality. Work, 53(4) 825-834.

11. Demartini, J. (2010). How our perceptions affect our health. Retrieved from https://drdemartini.com/writings_ and_insights/how_our_perceptions affect our health.

12. Fasoli, D. R. (2010). The culture of nursing engagement: a historical perspective. Nursing Administration Quarterly, 34(1), 18-29.

13. Ferri, P., Guadi, M., Marcheselli, L., Balduzzi, S., Magnani, D., \& Di Lorenzo, R. (2016). The impact of shift work on the psychological and physical health of nurses in a general hospital: a comparison between rotating night shifts and day shifts. Risk management and healthcare policy, 9, 203.

14. Giallonardo, L. M., Wong, C. A., \& Iwasiw, C. L. (2010). Authentic leadership of preceptors: predictor of new graduate nurses' work engagement and job satisfaction. Journal of nursing management, 18, 993-1003.

15. Görgens-Ekermans, G., Delport, M., \& Du Preez, R. (2015). Developing Emotional Intelligence as a key psychological resource reservoir for sustained student success. SA Journal of Industrial Psychology, 41(1), 1-13.

16. Hagmaier, T., \& Abele, A. (2015). When reality meets ideal: Investigating the relation between calling and life satisfaction. Journal of Career Assessment, 23(3), 367-382.

17. Hair, J., Black, B., Balbin, B., Anderson, R., \& Tatham, R. (2006). Multivariate Data Analysis (6th edn.). Tatham: Prentice Hall.

18. Hess, U. (2003). Emotions at work. Montreal: University of Montreal.

19. Iskra-Golec, I., Barnes-Farrell, J., \& Bohle, P. (Eds.). (2016). Social and Family Issues in Shift Work and Non Standard Working Hours. Springer.

20. Jöreskog, K. \& Sörbom, D. (2002). LISREL 8.52. Scientific Software International Inc.

21. Karimi, L., Leggat, S., Donohue, L., Farrell, G., \& Couper, G. (2013). Emotional rescue: The role of emotional intelligence and emotional labour on well-being and job-stress among community nurses. Journal of Advanced Nursing, 70(1), 176-186.

22. Kinman, G., \& Leggetter, S. (2016). Emotional Labour and Wellbeing: What protects nurses? Healthcare, 4(4), 89.

23. Khamisa, N., Peltzer, K., \& Oldenburg, B. (2013). Burnout in relation to specific contributing factors and health outcomes among nurses: A systematic review. International journal of environmental research and public health, 10(6), 2214-2240.

24. Leggat, S., Donohue, L., \& Couper, G. (2013). Emotional Rescue: The Role of Emotional Intelligence and Emotional Labour of Well-Being and Job-Stress among Community Nurses. Journal of Advanced Nursing, 70(10), 1-11.

25. Liang, Y., Hsieh, Y., Lin, Y. \& Chen, W. (2014). The impact of job stressors on health-related quality of life of nursing assistants in long-term care settings. 
Geriatric Nursing, 35, 114-119.

26. Merkel, C. (2002). Professional Ideology and the Practice of Work: Nurses' Caring Work in a Surgical Intensive Care Unit. New York, NY: City University of New York.

27. Morris, J., \& Feldman, D. (1996). The dimensions, antecedents, and consequences of emotional labor. Academy of Management Review, 21, 986-1010.

28. Murray, C. (2015). Who wants to live forever? The Economist, August.

29. Nunnally, J. (1978). Psychometric theory. New York: McGraw-Hill.

30. Ouweneel, E., Le Blanc, P. M., \& Schaufeli, W. B. (2013). Do-ityourself: An online positive psychology intervention to promote positive emotions, self-efficacy, and engagement at work. Career Development International, 18(2), 173-195.

31. Pélissier, C., Fontana, L., Fort, E., Vohito, M., Sellier, B., Perrier, C., Glerant, V., Couprie, F., Agard, J.P. \& Charbotel, B. (2015). Impaired mental well-being and psychosocial risk: a cross-sectional study in female nursing home direct staff. BMJ open, 5(3), e007190.

32. Peters, V., Houkes, I., de Rijk, A., Bohe, P., Engels, J., \& Nijhuis, J. (2016). Which resources moderate the effects of demanding work schedules on nurses working in residential elder care? A longitudinal study. International Journal of Nursing Studies, 58, 31-46.

33. Pisanti, R., Van der Doef, M., Maes, S., Lombardo, C., Lazzari, D., \& Violani, C. (2015). Occupational coping self-efficacy explains distress and wellbeing in nurses beyond psychosocial job characteristics. Frontier Psychology, 6, $1-14$.
34. Pluess, M., \& Belsky, J. (2013). Vantage Sensitivity: Individual Differences in Response to Positive Experiences. Psychological Bulletin, 139(4), 901916.

35. Salanova, M., Lorente, L., Chambel, M., \& Martinez, I. (2011). Linking transformational leadership to nurses' extra-role performance. The mediating role of self-efficacy and work engagement. Journal of Advances in Nursing, 67(10), 2256-2266.

36. Seligman, M., \& Csikszentmihalyi, M. (2000). Positive psychology: An introduction. American Psychologist, 55, 5-14.

37. Sexton, J. B., Thomas, E. J., \& Helmreich, R. L. (2000). Error, stress, and teamwork in medicine and aviation: cross sectional surveys. BMJ, 320(7237), 745-749.

38. Smith, P., \& Lorentzon, M. (2005). Is emotional labour ethical? Nursing Ethics, 12(6), 638-642.

39. Statistics South Africa. (2015). Stats SA Yearly Archives: 2015. Retrieved from Stats SA: www.statssa.gov.za/?m=2015.

40. Tahghighi, M., Rees, C.S., Brown, J.A., Breen, L.J., \& Hegney, D. (2017). What is the impact of shift work on the psychological functioning and resilience of nurses? An integrative review. Journal of Advanced Nursing 73(9), 2065-2083.

41. Tak, S., Sweeney, M., Alterman, T., Baron, S., \& Calvert, G. (2010). Workplace Assaults on Nursing Assistants in US Nursing Homes: A Multilevel Analysis. American Journal of Public Health, 100(10), 1938-1945.

42. Vermaak, C. (2016). The development and empirical evaluation of a psychological well-being at work structural model for geriatric care staff. Master's dissertation. Stellenbosch: University of Stellenbosch. 
43. Von Treuer, K., Fuller-Tyszkiewics, M., \& Little, G. (2014). The impact of shift work and organisational work climate on health outcomes of nurses. Journal of Occupational Health Psychology, 19(4), 453-461.

44. Xantopoulou, D., Bakker, A., Demerouti, E., \& Schaufeli, W. (2009).
Reciprocal relationships between job resources, personal resources, and work engagement. Journal of Vocational Behavior, 74, 235-244.

\section{RAD U SMJENAMA, EMOCIONALNI ANGAŽMAN I PSIHOLOŠKA DOBROBIT U SESTRINSTVU}

\section{Sažetak}

U ovom se radu istražuju efekti emocionalnog angažmana $i$ psihološko iskustvo rada u smjenama na psihološku dobrobit na radnom mjestu u dugoročnom radu u sestrinstvu $(N=206)$. Konstrukt "psihološkog iskustva rada u smjenama" određuje percepciju negativnih efekata, koje rad u smjenama ima na svakodnevni život. U radu su korištene metode korelacije $i$ multiple regresijske analize. Pritom su pronađeni empirijski dokazi za postojanje negativnog odnosa između psihološkog iskustva rada u smjenama $i$ psihološke dobrobiti na radnom mjestu (PDRM), kao $i$ efekata emocionalnog angažmana $i$ PDRM-a. Hijerarhijska regresija ukazuje da, kada se kontroliraju efekti emocionalnog angažmana $i$ određeni demografski čimbenici (uključujući broj ovisnih osoba u obitelji, duljinu radnog staža $i$ konkretnu smjenu u kojoj osoba radi), značajna varijanca PDRM-a može se objasniti psihološkim iskustvom rada u smjenama. Dobiveni rezultati ukazuju da na PDRM u sestrinstvu ne utječe samo smjena (dnevna ili noćna) u kojoj osoba radi, već prvenstveno osobno psihološko iskustvo rada u smjenama.

Ključne riječi: rad u smjenama, emocionalni angažman, psihološka dobrobit, sestrinstvo 


\section{Appendix A}

\section{PSYCHOLOGICAL EXPERIENCE OF SHIFT WORK - ITEMS}

1. Working shifts disrupts my life.

2. Working shifts disrupts the lives of my close relatives.

3. I have more trouble organizing my home life due to shift work.

4. Transport is an issue because I work shifts.

5. Workings shifts disrupts my social life.

6. Working shifts negatively impacts my health.

7. Life would be easier if I wasn't working shifts. 